\title{
The Influence of Maximal Aerobic Capacity on the Two Years Cardiac Related Re-Hospitalization in Patients with Heart Failure with Reduced Ejection Fraction in Korean Society
}

\author{
Ho Youl Ryu', Do Sun Hong', Tack Hoon Kim² \\ 'Department of Rehabilitation Medical Team, Yong-In Severance Hospital, Yonsei University Health System, Yongin; ${ }^{2}$ Department of Physical \\ Therapy, Hanseo University, Seosan, Korea
}

Purpose: This study examined the influence of the maximal aerobic capacity on the two-year cardiac-related re-hospitalization in patients with heart failure with a reduced ejection fraction (HFrEF) in Korean society.

Methods: The maximal aerobic capacity of the study population $(n=95$, male $63 \%)$ was evaluated using a cardiopulmonary exercise (CPX) testing system. Each patient was followed up for two years to divide the HFrEF patients into two groups according to cardiac-related re-hospitalization: re-hospitalization $(\mathrm{RH})$ group $(\mathrm{n}=29,30 \%)$ and no re-hospitalization $(\mathrm{NRH})$ group $(\mathrm{n}=66,70 \%)$.

Results: The relative peak $\mathrm{VO}_{2}(\mathrm{~mL} / \mathrm{kg} / \mathrm{min}, \mathrm{p}<0.001)$, exercise duration $(\mathrm{p}<0.001)$, respiratory exchange ratio $\left(\mathrm{VCO}_{2} / \mathrm{NO}_{2}, \mathrm{p}=0.001\right)$, systolic blood pressure (SBP) reserve $(p=0.004)$, heart rate (HR) reserve $(p=0.007)$, SBP $\max (p=0.02)$, and HR max $(p=0.039)$ were significantly lower in the RH group than the NRH group during the CPX test. On the other hand, the ventilatory efficiency (VENCO2 slope, $p=0.02)$ and age $(p=0.022)$ were significantly higher in the RH group than in the NRH group. In binary logistic regression analysis, the relative peak $\mathrm{VO}_{2}(p=0.001$, Wald Chi-square 10.137) was the strongest predictive factor on cardiac-related re-hospitalization, which was followed by $\mathrm{VCO}_{2} \mathrm{NO}_{2}(p=0.019$, Wald Chi-square 5.54). On the other hand, age $(p=0.063$, Wald Chi-square 3.445) did not have a significant influence on cardiac related re-hospitalization.

Conclusion: The maximal aerobic capacity, especially the relative peak $\mathrm{VO}_{2}$, is the strongest factor on cardiac-related re-hospitalization within two years in patients with HFrEF in Korean society.

Keywords: Heart failure, Cardiopulmonary exercise test, Maximal aerobic capacity, Relative peak $\mathrm{VO}_{2}$, Re-hospitalization

\section{서 론}

심부전(heart failure)이란 심장의 구조적 혹은 기능적 이상으로 인해 왼심실의 이완 또는 수축 능력이 저하되어 일상생활 중 숨찬 증세, 다 리 부종, 피로 등의 증상을 동반하는 임상 증후군으로 정의된다.' 심 부전이 장기화되면 호흡 곤란과 피로 ${ }^{2}$ 등을 이유로 일상생활 활동량 이 감소하게 되고 근육량 감소, ${ }^{3}$ 노쇠(frailty), ${ }^{4,5}$ 재입원율과 사망률 증 가 ${ }^{6,7}$ 등으로 이어져 심부전 환자의 삶의 질 하락뿐만 아니라 개인과 사회의 의료비용이 더욱 증가하게 된다. 한국 사회 심부전 환자의 의 료비용 지출에 대한 정확한 통계자료는 없으나, 영국 국립보건원 통 계자료에 따르면 영국 사회 심부전 환자의 전체 의료비용 중 $70 \%$ 가 입원 치료에 이용되었으며, 고령화로 인해 25년 내에 입원 치료비 지
출이 $50 \%$ 이상 증가할 것이라고 보고한 바 있다. ${ }^{6}$

심부전은 발병원인에 따라 급성 심근경색(myocardial infarction)으 로 심장근육이 손상, 괴사되어 왼심실 수축력이 저하되는 허혈성 심 근증(ischemic cardiomyopathy)과 관상동맥 폐색과 관계없이 고혈압 등을 원인으로 발생하는 확장성 심근병증(dilated cardiomyopathy)과 같은 비허혈성 심근증(non-ischemic cardiomyopathy)으로 분류되지

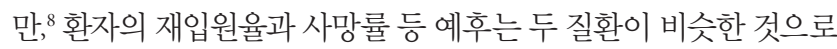
알려져 있다.9 반면에, 심근 수축력 저하 정도에 따른 분류에서는 심 부전 환자의 예후에 유의한 차이가 나타난다.10 안정 시 심장 초음파 (echocardiogram) 검사에서 왼심실 박출률(left ventricular ejection fraction, LVEF)이 55\% 이상인 경우를 정상으로 분류하지만, LVEF가 50-54\%인 경우에는 박출률 보존형 심부전, $40-49 \%$ 인 경우에는 경계 
형 심부전, $39 \%$ 이하인 경우에는 박출률 감소형 심부전(heart failure with reduced ejection fraction, $\mathrm{HFrEF})$ 으로 분류한다.8 이 중 $\mathrm{HFrEF}$ 환 자의 경우에는 경계형이나 보존형에 비해 재입원율과 사망률이 높다 고 보고되고 있다. ${ }^{4,6,710}$

$\mathrm{HFrEF}$ 환자의 예후 예측에 있어 중요하게 여겨지는 또 다른 요인은 최대 유산소 운동능력이다. 해외의 다수 선행연구에 따르면 운동부 하 심폐기능(cardiopulmonary exercise test, $\mathrm{CPX}$ ) 검사를 이용한 최대 운동 중 호흡 가스, 특히 체중을 고려한 상대적 최고 산소섭취량 $(\mathrm{mL} /$ $\mathrm{kg} / \mathrm{min}$ )이 저하될수록 환자의 재입원율과 사망률이 높아진다고 보 고하여 왔다.711,12 그러나 아직까지 한국 사회에서는 심부전 진단 후 LVEF 등 기초 임상 정보와 최대 유산소 운동능력이 심장질환 관련 재입원에 어떠한 영향을 미치는지 분석한 연구는 부족한 실정에 있 다. 특히, 중증 심부전에 해당하는 $\mathrm{HFrEF}$ 환자를 대상으로 한 국내 연 구는 거의 없는 실정에 있다. 이에, 본 연구는 한국 사회에서 심부전을 최초로 진단받고 입원치료 후 퇴원한 환자 중 재입원율이 상대적으 로 높은 $\mathrm{HFrEF}$ 환자를 대상으로 하여 심장 초음파, $\mathrm{CPX}$ 검사 결과 등 다양한 임상 검사 정보가 2년 내 심장질환 악화에 의한 재입원에 어 떠한 영향을 미치는지 분석하여 재입원율 감소를 위한 치료적 전략 수립에 도움이 될 수 있는 근거자료 제공을 목적으로 진행되었다.

\section{연구 방법}

\section{1. 연구대상}

본 연구는 Y의료원에서 심부전을 최초로 진단받고 입원치료 후 퇴원 한 $\mathrm{HFrEF}$ 환자를 대상으로 하였다. 급성 심근경색으로 경피적 관상 동맥 중재술(percutaneous coronary intervention)을 시행받은 환자(31 명)와 확장성 심근병증으로 약물치료를 받은 환자(64명) 95명을 대상 으로 하였다. 관상동맥 우회로술이나 판막 치환술 등 외과적 수술을 실시한 환자는 최소 1 개월 이상 절대적 안정을 필요로 하기 때문에 연구 대상에서 제외하였다. $\mathrm{HFrEF}$ 환자의 최대 유산소 운동능력을 검사하기 위해 심장내과 주치의의 처방에 따라 $\mathrm{CPX}$ 검사를 실시하 였다. CPX 검사 완료 후 검사 결과에 따라 각각의 대상자들은 심장호 흡 전문 물리치료사에게 운동방법을 교육받았으며, 전문 간호사에 게 베타 블로커나 이뇨제 등 처방받은 약물복용법에 관한 교육을 받 았다. CPX 검사와 교육을 마친 후로부터 2년 동안 심장질환 악화에 의한 재입원 여부를 추적 조사하였다. 심장질환 악화에 의한 재입원 여부는 실신이나 호흡곤란 악화 등을 이유로 응급실을 통해 재입원 한 경우로 하였다. 2 년 동안의 추적 조사 기간 내에 거주지역 문제로 병원을 옮긴 경우나 다른 원인에 의한 사망 등으로 추적 조사가 불가 한 경우에는 연구 대상에서 제외하였다. 추적 조사 완료 후 2 년 이내 에 심장질환 악화로 인해 재입원한 집단(re-hospitalization, RH)과 재
입원 이력이 없었던 집단(no re-hospitalization, $\mathrm{NRH}$ )으로 분류하였으 며, 두 집단의 일반적 특성은 Table 1과 같다.

\section{2. 실험방법}

\section{1) 실험절차}

심장내과 전문의의 $\mathrm{CPX}$ 처방을 받은 $\mathrm{HFrEF}$ 환자의 최대 유산소 운 동능력 측정을 위해 트레드밀을 이용하였다. CPX 검사에 이용한 프 로토콜은 20 초 간격으로 운동강도가 미세하게 증가하여 심장 질환 및 노약자에게 적합한 것으로 알려진 modified Bruce ramp 프로토콜 이다. ${ }^{13,14} \mathrm{CPX}$ 검사 중 발생할 수 있는 심실 빈맥(ventricular tachycar$\mathrm{dia})$ 과 같은 응급 사고를 예방하기 위해 실시간 12-전극 표면 심전도 를 부착하였다. 트레드밀 운동 중 흔들림에 의한 심전도 잡음을 최소 화하기 위하여 표면 전극 부착 전 피부 표면의 잔털을 제거하고 알코 올로 소독하였으며, 흥부 코르셋(corset)을 착용하였다. 최대 운동 중 측정된 호흡 가스 자료는 2 초마다 측정된 값을 20 초 평균값으로 표준 화(filtering)하였으며 심박수, 수축기 혈압 등 활력 징후(vital sign)는 3 분마다측정하여 통계분석에 이용하였다. ${ }^{15}$

\section{2) 측정도구}

$\mathrm{CPX}$ 검사 증 심전도 감시와 활력 징후 측정은 트레드밀 운동부하 검 사 시스템(treadmill exercise testing system, CASE T2100, GE, USA)을 이 용하였으며, 호흡 가스 측정은 Quark gas analyze system (COSMED, IL,

Table 1. General characteristics of subject

\begin{tabular}{lccc}
\hline & $\begin{array}{c}\mathrm{RH} \\
(\mathrm{n}=29,30 \%)\end{array}$ & $\begin{array}{c}\mathrm{NRH} \\
(\mathrm{n}=66,70 \%)\end{array}$ & $\mathrm{p}$-value \\
\hline Male & $\mathrm{n}=15,25 \%$ & $\mathrm{n}=45,75 \%$ & \\
Female & $\mathrm{n}=14,40 \%$ & $\mathrm{n}=21,60 \%$ & \\
Age (yr) & $63.53 \pm 13.21$ & $56.96 \pm 13.04$ & $0.022^{*}$ \\
Height (cm) & $161.83 \pm 8.47$ & $164.45 \pm 8.98$ & $>0.05$ \\
Weight (kg) & $59.43 \pm 13.34$ & $65.44 \pm 14.39$ & $>0.05$ \\
BMI (kg/m $\left.{ }^{2}\right)$ & $22.60 \pm 4.34$ & $24.04 \pm 3.96$ & $>0.05$ \\
Myocardial infraction & $8(26 \%)$ & $23(74 \%)$ & $>0.05$ \\
Dilated cardiomyopathy & $21(23 \%)$ & $43(77 \%)$ & $>0.05$ \\
Atrial fibrillation & $10(34 \%)$ & $14(21 \%)$ & $>0.05$ \\
Diabetes mellitus & $12(41 \%)$ & $16(24 \%)$ & $0.022^{*}$ \\
Hypertension & $16(55 \%)$ & $27(41 \%)$ & $>0.05$ \\
HR rest (beat/min) & $84.25 \pm 17.50$ & $84.91 \pm 17.64$ & $>0.05$ \\
SBP rest (mmHg) & $107.60 \pm 17.06$ & $108.47 \pm 19.92$ & $>0.05$ \\
LVEF (\%) & $26.47 \pm 7.23$ & $28.14 \pm 8.36$ & $>0.05$ \\
ACEl medication & $\mathrm{n}=27,91 \%$ & $\mathrm{n}=62,93 \%$ & $>0.05$ \\
Beta-blocker & $\mathrm{n}=26,89 \%$ & $\mathrm{n}=63,95 \%$ & $>0.05$ \\
\hline
\end{tabular}

$\mathrm{M} \pm \mathrm{SD}$. RH: re-hospitalization, NRH: no re-hospitalization, BMl: body mass index, HR: heart rate, SBP: systolic blood pressure, LVEF: left ventricular ejection faction, ACEl: angiotensin-converting enzyme inhibitor.

${ }^{*} \mathrm{p}<0.05$. 
Italy)을 이용하였다(Figure 1).

\section{3. 통계분석}

본 연구에서 측정된 자료의 통계 처리는 SPSS version 23.0 (statistical package for social science, IBM Corp., USA) 프로그램을 이용하였다. $\mathrm{RH}$ 집단과 $\mathrm{NRH}$ 집단의 일반적 특성과 $\mathrm{CPX}$ 검사에서 측정된 호흡 가스, 활력 징후는 기술적 통계를 이용하여 평균 값과 표준 편차로 산출하였으며 두 집단 간 차이는 독립 표본 t-검정을 이용하였다. RH

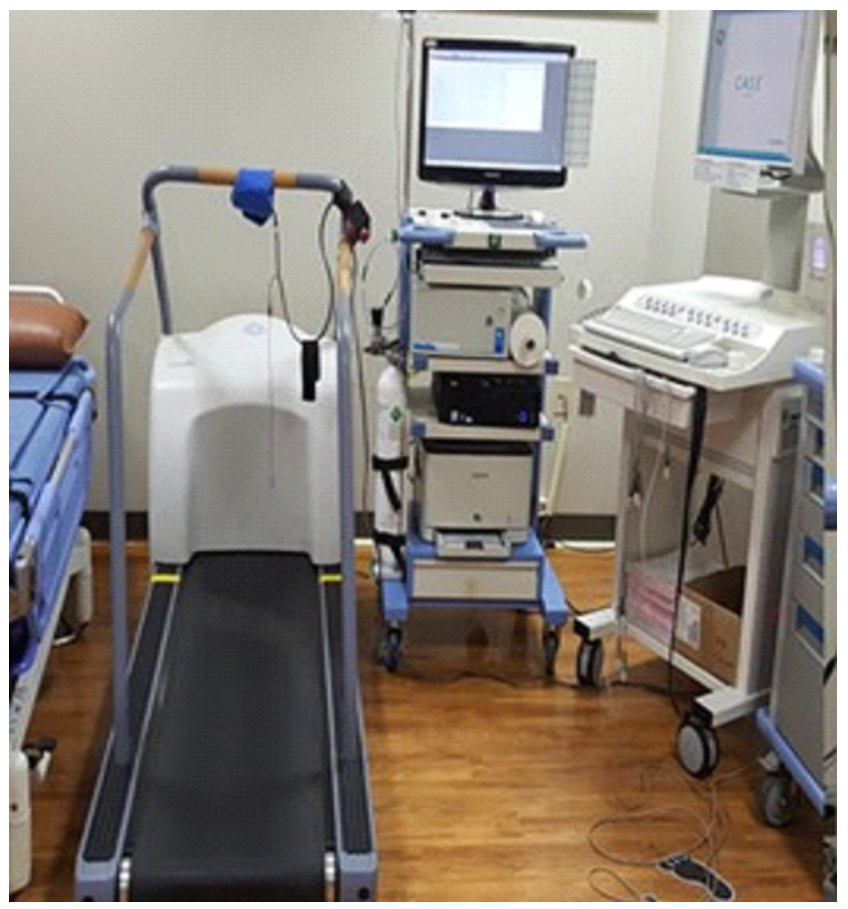

Figure 1. Cardiopulmonary exercise testing system.
집단과 $\mathrm{NRH}$ 집단의 최대 운동 중 측정된 호흡 가스와 활력 징후가 2 년 내 재입원에 미치는 영향에 관한 분석은 이분형 로지스틱 회귀분 석(binary logistic regression analysis)을 이용하였다. 통계학적 유의 수 준은 $\mathrm{p}<0.05$ 로 하였다.

\section{결 과}

\section{1. $\mathrm{HFrEF}$ 환자의 기초 임상 정보와 재입원}

총 95명의 $\mathrm{HFrEF}$ 환자를 대상으로 2년 내 심장질환 악화에 의한 재입 원 여부에 따라 RH 집단과 $\mathrm{NRH}$ 집단으로 분류한 후 기초 임상 정보 의 집단 간 차이를 분석한 독립 표본 $\mathrm{t}$-검정 결과, $\mathrm{RH}$ 집단의 나이 $(\mathrm{p}<0.05)$ 가 $\mathrm{NRH}$ 집단에 비해 유의하게 많았으며, 당뇨병 진단을 받 은 환자 $(\mathrm{p}<0.05)$ 에서 재입원율이 유의하게 높은 것으로 나타났다

Table 3. Differences between group in respiratory and hemodynamic response during $\mathrm{CPX}$

\begin{tabular}{lcccc}
\hline & $\begin{array}{c}\mathrm{RH}(\mathrm{n}=29, \\
30 \%)\end{array}$ & $\begin{array}{c}\mathrm{NRH}(\mathrm{n}=66, \\
70 \%)\end{array}$ & $\mathrm{t}$ & $\mathrm{p}$ \\
\hline Peak $\mathrm{VO}_{2}(\mathrm{~mL} / \mathrm{kg} / \mathrm{min})$ & $15.80 \pm 3.18$ & $21.62 \pm 5.19$ & -5.583 & $<0.001^{* *}$ \\
$\mathrm{ED}(\mathrm{sec})$ & $391.60 \pm 140.90$ & $599.84 \pm 169.51$ & -6.222 & $<0.001^{* *}$ \\
$\mathrm{VCO}_{2} \mathrm{NO}_{2}$ & $1.04 \pm 0.80$ & $1.11 \pm 0.07$ & -3.557 & $0.001^{* *}$ \\
VE $\mathrm{NCO}_{2}$ slope & $39.79 \pm 8.41$ & $35.42 \pm 7.48$ & 2.407 & $0.02^{*}$ \\
HR max (beat/min) & $129 \pm 24$ & $141 \pm 28$ & -2.112 & $0.039^{*}$ \\
HR reserve (beat/min) & $45 \pm 16$ & $56 \pm 23$ & -2.765 & $0.007^{*}$ \\
SBP max (mmHg) & $142 \pm 25$ & $157 \pm 32$ & -2.373 & $0.02^{*}$ \\
SBP reserve (mmHg) & $35 \pm 19$ & $49 \pm 25$ & -2.95 & $0.004^{*}$ \\
\hline
\end{tabular}

$\mathrm{M} \pm \mathrm{SD}$. RH: re-hospitalization, $\mathrm{NRH}$ : no re-hospitalization, ED: exercise duration, VE: minute ventilation, HR: heart rate, SBP: systolic blood pressure. ${ }^{*} p<0.05,{ }^{* *} p \leq 0.001$.

Table 2. Binary logistic regression analysis between re-hospitalization and general characteristics

\begin{tabular}{|c|c|c|c|c|c|c|c|c|}
\hline & & \multirow{2}{*}{ Beta } & \multirow{2}{*}{ SE } & \multirow{2}{*}{$\begin{array}{c}\text { Wald } \\
\text { Chi-square }\end{array}$} & \multirow{2}{*}{$\mathrm{p}$-value } & \multirow{2}{*}{ Odds ratio } & \multicolumn{2}{|c|}{$95 \% \mathrm{Cl}$} \\
\hline & & & & & & & Upper & Lower \\
\hline \multirow[t]{12}{*}{$\mathrm{RH}$} & Age (yr) & 0.042 & 0.019 & 4.796 & $0.029^{*}$ & 1.043 & 1.004 & 1.083 \\
\hline & Weight (kg) & -0.028 & 0.020 & 1.996 & 0.158 & 0.972 & 0.935 & 1.011 \\
\hline & Height $(\mathrm{cm})$ & 0.023 & 0.218 & 0.011 & 0.916 & 1.023 & 0.667 & 1.569 \\
\hline & $\mathrm{BMI}\left(\mathrm{kg} / \mathrm{m}^{2}\right)$ & 0.037 & 0.132 & 0.078 & 0.780 & 1.038 & 0.801 & 1.345 \\
\hline & HR rest (beat/min) & 0.001 & 0.015 & 0.001 & 0.981 & 1.000 & 0.970 & 1.030 \\
\hline & $\mathrm{SBP}$ rest $(\mathrm{mmHg})$ & -0.008 & 0.015 & 0.282 & 0.596 & 0.992 & 0.963 & 1.022 \\
\hline & $\operatorname{LVEF}(\%)$ & -0.038 & 0.030 & 1.613 & 0.204 & 0.963 & 0.908 & 1.021 \\
\hline & Ischemic & -0.390 & 0.585 & 0.445 & 0.505 & 0.677 & 0.215 & 2.130 \\
\hline & Diabetes mellitus & -0.644 & 0.496 & 1.690 & 0.194 & 0.525 & 0.199 & 1.387 \\
\hline & Atrial fibrillation & -0.637 & 0.528 & 1.455 & 0.228 & 0.529 & 0.188 & 1.489 \\
\hline & Hypertension & -0.362 & 0.526 & 0.473 & 0.492 & 0.696 & 0.249 & 1.952 \\
\hline & Constant term & -3.374 & 1.215 & 7.713 & $0.005^{*}$ & 0.034 & & \\
\hline
\end{tabular}

SE: standard error, Cl: confidence interval, RH: re-hospitalization, HR: heart rate, SBP: systolic blood pressure, LVEF: left ventricular ejection faction. ${ }^{*} p<0.05$. 
Table 4. Binary logistic regression analysis between re-hospitalization and CPX parameters

\begin{tabular}{|c|c|c|c|c|c|c|c|c|}
\hline & & \multirow{2}{*}{ Beta } & \multirow{2}{*}{ SE } & \multirow{2}{*}{$\begin{array}{c}\text { Wald } \\
\text { Chi-square }\end{array}$} & \multirow{2}{*}{ p-value } & \multirow{2}{*}{ Odds ratio } & \multicolumn{2}{|c|}{$95 \% \mathrm{Cl}$} \\
\hline & & & & & & & Lower & Upper \\
\hline \multirow[t]{9}{*}{$\mathrm{RH}$} & peak $\mathrm{VO}_{2}(\mathrm{~mL} / \mathrm{kg} / \mathrm{min})$ & -0.388 & 0.122 & 10.137 & $0.001^{* *}$ & 0.678 & 0.534 & 0.861 \\
\hline & $\mathrm{VCO}_{2} \mathrm{NO}_{2}$ & -10.407 & 4.422 & 5.54 & $0.019^{*}$ & 0.000 & 0.001 & 0.175 \\
\hline & Age (yr) & 0.055 & 0.029 & 3.445 & 0.063 & 1.056 & 0.997 & 1.119 \\
\hline & SBP reserve $(\mathrm{mmHg})$ & -0.027 & 0.016 & 2.951 & 0.086 & 0.973 & 0.944 & 1.004 \\
\hline & HR reserve (beat/min) & 0.007 & 0.019 & 0.143 & 0.705 & 1.007 & 0.970 & 1.046 \\
\hline & SBP max (mmHg) & 0.007 & 0.021 & 0.109 & 0.741 & 1.007 & 0.966 & 1.050 \\
\hline & HR max (beat/min) & -0.007 & 0.020 & 0.121 & 0.728 & 0.993 & 0.956 & 1.032 \\
\hline & VE $/ \mathrm{NCO}_{2}$ slope & 0.000 & 0.059 & 0.032 & 0.859 & 0.990 & 0.882 & 1.110 \\
\hline & Constant term & 16.982 & 5.689 & 8.910 & & & & \\
\hline
\end{tabular}

SE: standard error, Cl: confidence interval, RH: re-hospitalization, SBP: systolic blood pressure, HR: heart rate, VE: minute ventilation. ${ }^{*} p<0.05,{ }^{* *} p \leq 0.001$.

(Table 1). 그러나 LVEF, 체질량 지수 등 다른 요인에서는 두 집단 사이 에 유의한 차이가 없었다. 각각의 요인들의 상호 영향력을 보정하기 위해 실시한 이분형 로지스틱 회귀분석에서는 유일하게 나이 $(\mathrm{p}<0.05)$ 가 재입원에 유의한 영향을 미치는 것으로 분석되었으며 당뇨는 유 의하지 않은 것으로 나타났다(Table 2).

\section{HFrEF 환자의 최대 유산소 운동능력과 재입원}

총 95 명의 $\mathrm{HFrEF}$ 환자를 대상으로 2 년 내 심장질환 악화에 의한 재입 원 여부에 따라 $\mathrm{RH}$ 집단과 $\mathrm{NRH}$ 집단으로 분류한 후 $\mathrm{CPX}$ 검사에서 측정된 최대 운동 중 호흡 가스와 활력 징후의 집단 간 차이를 알아 보기 위해 실시한 독립 표본 $\mathrm{t}$-검정 결과는 Table 3 과 같다.

$\mathrm{RH}$ 집단과 $\mathrm{NRH}$ 집단의 체중 차이를 고려한 상대적 최고 산소섭 취량은 각각 $15.80 \pm 3.18,21.62 \pm 5.19 \mathrm{~mL} / \mathrm{kg} / \mathrm{min}$ 으로 측정되어 $\mathrm{NRH}$ 집단이 유의하게 높게 나타났다 $(\mathrm{p} \leq 0.001)$. 운동 지속시간은 각각 $391.60 \pm 140.90,599.84 \pm 169.51$ 초로 측정되어 NRH 집단이 유의하게 높게 나타났다 $(\mathrm{p} \leq 0.001)$. 호흡 교환율 $\left(\mathrm{VCO}_{2} / \mathrm{VO}_{2}\right)$ 은 각각 $1.04 \pm 0.80$, $1.11 \pm 0.07$ 로 측정되어 $\mathrm{NRH}$ 집단이 유의하게 높게 나타났다 $(\mathrm{p} \leq 0.001)$. $\mathrm{VE} / \mathrm{VCO}_{2}$ slope 항목이 $35.42 \pm 7.48$ 로 측정되어 $\mathrm{NRH}$ 집단이 유의하게 낮게 나타났다 $(\mathrm{p}<0.05)$. RH 집단과 $\mathrm{NRH}$ 집단의 최대 심박수는 각각 $129 \pm 24,141 \pm 28 \mathrm{beat} / \mathrm{min}$ 으로 측정되어 $\mathrm{NRH}$ 집단이 유의하게 높게 나타났다 $(\mathrm{p}<0.05)$. 여유 심박수는 각각 $45 \pm 16,56 \pm 23$ beat $/ \mathrm{min}$ 으로 측정되어 $\mathrm{NRH}$ 집단이 유의하게 높게 나타났다 $(\mathrm{p}<0.05)$. 최대 수축기 혈압은 각각 $142 \pm 25,157 \pm 32 \mathrm{mmHg}$ 로 측정되어 $\mathrm{NRH}$ 집단이 유의하 게 높게 나타났다 $(\mathrm{p}<0.05)$. 여유 수축기혈압은 각각 $35 \pm 19,49 \pm 25$ $\mathrm{mmHg}$ 로 측정되어 $\mathrm{NRH}$ 집단이 유의하게 높게 나타났다 $(\mathrm{p}<0.05)$.

최대 운동 중 측정된 호흡 가스와 활력 징후, 그리고 $\mathrm{HFrEF}$ 환자의 기초 임상 정보 중 재입원에 유의한 영향을 미치는 나이를 포함하여 실시한 이분형 로지스틱 회귀분석 결과는 Table 4 와 같다. 재입원에 가장 강한 영향을 미치는 요인은 상대적 최고 산소섭취량 $(\mathrm{mL} / \mathrm{kg} /$ $\min , \mathrm{p} \leq 0.001)$ 이었으며, 호흡 교환율( $\mathrm{p}<0.05)$ 순으로 유의한 영향을 미치는 것으로 나타나 나이 $(\mathrm{p}>0.05)$ 보다 더욱 강한 영향을 미치는 것 으로 분석되었다.

\section{고 찰}

본 연구는 한국 사회 $\mathrm{HFrEF}$ 환자의 심부전 최초 진단 시 기초 임상 정보와 최대 유산소 운동 능력이 2년 내 심장질환 악화로 인한 재입 원율에 어떠한 영향을 미치는지 분석하기 위한 목적으로 진행되었 다. 2 년 내 심장질환 악화로 인해 재입원한 집단( 29 명, $30 \%)$ 과 재입원 이력이 없었던 집단(66명, $70 \%)$ 의 기초 임상 정보 중 나이와 당뇨 진단 비율에서 집단 간 유의한 차이가 있었다. 그러나 LVEF, 체질량 지수 등 다른 기초 임상 정보에서는 집단 간 유의한 차이가 없었다. 심부전 환자의 재입원율에 영향을 미칠 것으로 생각된 LVEF에서 집단 간 유 의한 차이가 없었던 것은 의외의 결과였으나, LVEF가 $39 \%$ 이하인 중 증의 심부전 환자만을 연구 대상으로 제한했기 때문인 것으로 생각 된다. $\mathrm{HFrEF}$ 환자의 다양한 기초 임상 정보들이 재입원에 미치는 상 호 영향력을 보정하기 위해 실시한 이분형 로지스틱 회귀분석 결과 에서는 유일하게 나이가 재입원에 영향을 미치는 것으로 분석되었고 당뇨는 유의한 영향이 없는 것으로 분석되었다.

$\mathrm{RH}$ 집단과 NRH집단의 최대 유산소 운동능력 측정을 위한 $\mathrm{CPX}$ 검사에서는 호흡 가스와 활력 징후 대부분의 요인에서 두 집단 간 유 의한 차이가 있었다. 최대 유산소 운동 중 측정된 다양한 호흡 가스 와 활력 징후가 재입원에 미치는 상호 영향력을 보정하기 위해 실시 한 이분형 로지스틱 회귀분석 결과, 체중을 고려한 상대적 최고 산소 섭취량 $\left(\mathrm{mL} / \mathrm{kg} / \mathrm{min}\right.$, Wald Chi square 10.137), 호흡 교환율 $\left(\mathrm{VO}_{2} / \mathrm{VCO}_{2}\right.$, Wald Chi square 5.54), 나이(Wald Chi square, 3.445) 순으로 재입원에 강한 영향을 미치는 것으로 나타났다. 호흡 교환율은 고강도 운동 시 산소 소비량과 이산화탄소 발생량의 비율로 결정되는데, 상대적 최 
고 산소 섭취량과 비슷하게 운동 강도가 높아질수록 높게 측정되기 때문에 최대 유산소 운동능력의 영향을 받는 요인이다. 본 연구에서 가장 주목할 점은 $\mathrm{HFrEF}$ 환자의 기초 임상 정보 중 재입원에 가장 강 한 영향을 미치는 것으로 분석된 나이에 비해 최대 유산소 운동 중 측정된 호흡 가스 요인들이 재입원율에 더욱 강한 영향을 미쳤다는 점이다. 이는 심부전 환자의 최대 유산소 운동능력 측정을 위한 $\mathrm{CPX}$ 검사가 다른 기초 임상 정보를 얻기 위한 검사와 함께 반드시 병행되 어야 한다는 것을 시사한다.

본 연구의 결과는 해외의 다수 선행연구와 비슷하였다. CPX 검사 결과와 $\mathrm{HFrEF}$ 환자의 예후에 관한 선행연구를 살펴보면, Keteyian 등근 이 미국사회 남성(71\%)과 여성(29\%) HFrEF 환자 2,100명을 대상으로 평균 32개월 동안 추적 조사한 결과 357 명(17\%)이 사망하였는데, 남 성은 상대적 최고 산소섭취량 $(\mathrm{mL} / \mathrm{kg} / \mathrm{min}$, Wald Chi-square 129), 이산 화탄소 환기당량 기울기(VE/ $\mathrm{VCO}_{2}$ slope, Wald Chi square 99), 여유 심 박수(Wald Chi square 73) 순으로 사망률에 강한 영향을 미쳤으며, 여 성에서는 이산화탄소 환기당량 기울기(Wald Chi square 28), 상대적 최고 산소 섭취량(Wald Chi square 25), 여유 심박수(Wald Chi square 22) 순으로 강한 영향을 미쳤다고 하였다. 또한 Corrà 등'이 유럽사회 749 명의 심부전 환자를 대상으로 평균 3 년 동안 추적 조사한 결과에 서도 139명(19\%)의 환자가 심장질환으로 사망하거나 심장이식 수술 을 받았는데, 비교 집단(81\%)에 비해 최대 유산소 운동 중 측정된 대 부분의 호흡 가스와활력 징후에서 두 집단 간 유의한 차이가 있었으 며, 상대적 최고 산소섭취량이 가장 강한 영향을 미쳤다고 하여 본 연 구 결과와 일치하였다. 선행연구와 본 연구 결과로 미루어 볼 때, 최대 유산소 운동 중 측정된 호흡 가스 요인이 활력 징후에 비해 $\mathrm{HFrEF}$ 환 자의 재입원율이나 사망률에 더욱 강한 영향을 미친다는 점을 확인 할수있었다.

한국 사회는 고령화로 인해 심부전 환자가 지속적으로 증가할 것 이며, 급사를 예방하는 삽입형 제세동기 등 의료 기술의 발달로 인해 환자의 수명 또한 증가할 것으로 예상된다. 이는 재입원율과 재입원 횟수의 증가로 이어져 개인과 사회의 의료비용 부담을 지속적으로 증가시킬 것이다. 그러므로 심부전 환자의 최대 유산소 운동능력 향 상과 재입원율 감소를 위한 미래 지향적 치료 계획의 수립이 필요하 다. Sagar 등이 유럽 사회 심부전 환자를 대상으로 병원중심 운동치 료가 재입원율에 미치는 영향을 체계적 문헌고찰(systemic review)한 연구를 살펴보면, 병원중심 운동치료와 약물치료를 병행한 집단이 약물치료만 실시한 집단에 비해 1 년 내 재입원율이 약 $25 \%$ 정도 감소 한다고 하였다. 또한 Ryu 등 ${ }^{16}$ 이 한국 사회 47 명의 만성 심부전 환자 를 대상으로 가정중심 유산소운동 여부를 조사한 후 12 개월 동안 재 입원율을 추적 조사한 결과에서도 가정중심 운동집단의 1년 내 재입 원율은 $7 \%$ 에 불과했지만 운동을 하지 않았던 집단의 재입원율은
$47 \%$ 로 유의하게 높았다고 하며 규칙적인 운동 프로그램의 지역사회 보급 필요성을 강조하였다.

그러므로, 본 연구 결과를 임상적 근거로 하여 심장 전문 물리치료 사는 심부전 환자의 최대 유산소 운동능력 향상을 위한 운동치료 프 로그램의 발달과 지역사회 보급에 앞장서 한국 사회 심부전 환자의 삶의 질 향상과 의료비용 지출 감소에 이바지해야할 것이다.

본 연구의 제한점은 심부전 최초 진단 시 기초 임상 정보와 최대 유산소 운동능력이 2년 내 심장질환 악화에 의한 재입원율에 어떠한 영향을 미치는지 분석하였으나, 체계적인 운동 치료적 중재나 관리 가 재입원율 감소에 어떠한 영향을 미치는지에 대한 분석은 하지 못 하였다. 향후의 연구자들은 병원이나 지역사회 중심 운동치료 프로 그램이 심부전 환자의 재입원율 감소에 어떠한 영향을 미치는지 분 석할 필요가 있다.

본 연구의 결론은 다음과 같다. 한국사회 $\mathrm{HFrEF}$ 환자의 최대 유산 소 운동능력이 다른 기초 임상 정보에 비해 2년 내 심장질환 악화에 의한 재입원에 강한 영향을 미쳤으며, 최대 유산소 운동 중 측정된 호 흡 가스가 활력 징후에 비해 재입원 예측에 더욱 강한 영향을 미치는 것으로 나타났다.

\section{REFERENCES}

1. Dickstein K, Cohen-Solal A, Filipppatos G et al. ESC Guidelines for the diagnosis and treatment of acute and chronic heart failure 2008: the Task Force for the diagnosis and treatment of acute and chronic heart failure 2008 of the European Society of Cardiology. Developed in collaboration with the Heart Failure Association of the ESC (HFA) and endorsed by the European Society of Intensive Care Medicine (ESICM). Eur J Heart Fail. 2008;10(10):933-89.

2. Chase P, Arena R, Myers J et al. Prognostic usefulness of dyspnea versus fatigue as reason for exercise test termination in patients with heart failure. Am J Cardiol. 2008;102(7):879-82.

3. Anker SD, Chua TP, Ponikowski P et al. Hormonal changes and catabolic/anabolic imbalance in chronic heart failure and their importance for cardiac cachexia. Circulation. 1997;96:526-34.

4. Burns RB, McCarthy EP, Moskowitz MA et al. Outcomes for older men and women with congestive heart failure. J AM Geriatr Soc. 1997;45:27680.

5. Miller MS, Vanburen P, Lewinter MM et al. Mechanisms underlying skeletal muscle weakness in human heart failure: alterations in single fiber myosin protein content and function. Heart Fail. 2009;2:700-6.

6. Sagar VA, Davies EJ, Briscoe $S$ et al. Exercise-based rehabilitation for heart failure: systematic review and meta-analysis. Open Heart. 2015;2(1): e000163.

7. Keteyian SJ, Patel M, Kraus WE et al. Variables measured during cardiopulmonary exercise testing as predictors of mortality in chronic systolic heart failure. J Am Coll Cardiol. 2016;67(7):780-9.

8. Choi HJ, Kang SM, Youn JC et al. Cheonical herat failure: 16 thins chaged, The Korean Society of Hear Failur. 2016. 
9. Rusnak J, Behnes M, Schupp T, et al. Comparable survival in ischemic and nonischemic cardiomyopathy secondary to ventricular tachyarrhythmias and aborted cardiac arrest. Coronary Artery Disease. 2019;304:303-11.

10. Muller J, Behnes M, Ellguth D et al. Prognostic impact of left ventricular ejection fraction in patients with electrical storm. J Interv Card Electrophysiol. 2019;55:307-15.

11. Corrà U, Giordano A, Mezzani A, et al. Cardiopulmonary exercise testing and prognosis in heart failure due to systolic left ventricular dysfunction: a validation study of the European Society of Cardiology Guidelines and Recommendations (2008) and further developments. Eur J Prev Cardiol. 2012;19:32-40.

12. Mancini DM, Mancini DM, Eisen $\mathrm{H}$ et al. Value of peak exercise oxygen consumption for optimal timing of cardiac transplantation in ambulato- ry patients with heart failure. Circulation. 1991;83:778-86.

13. Fletcher GF, Ades PA, Kligfield P et al Exercise standards for testing and training: A scientific statement from the american heart association. Circulation. 2013;128:873-934.

14. Kaminsky LA, Bonzheim KA, Garber CE et al. ACSM's resource manual for guidelines for exercise testing and prescription. 5th edition. Philadelphia, Lippincott Williams \& Wilkins. 2008.

15. Youn JC, Lee HS, Choi SW et al. Post-exercise heart rate recovery independently predicts clinical outcome in patients with acute decompensated heart failure. PLoS One. 2016;11(5):e0154534.

16. Ryu HY, Kim KS, Jeon IC. Influence of home based exercise intensity on the aerobic capacity and 1 Year re-hospitalization rate in patients with chronic heart failure. J Kor Phys Ther. 2018;30:181-6. 